Original article

\title{
Synthesis and antifungal activity of some substituted phenothiazines and related compounds
}

\author{
Gabriela P. Sarmiento $^{\text {a,e }}$, Roxana G. Vitale ${ }^{\text {b,c,* }}$, Javier Afeltra ${ }^{\text {c,d }}$, Graciela Y. Moltrasio ${ }^{\text {e }}$, \\ Albertina G. Moglioni ${ }^{\mathrm{a}, \mathrm{b}, *}$ \\ a Department of Pharmacology, Facultad de Farmacia y Bioquímica, Universidad de Buenos Aires, Junín 956, CABA, Argentina \\ ${ }^{\mathrm{b}}$ Consejo Nacional de Investigaciones Científicas y Tecnológicas (CONICET), Rivadavia 1917, CABA, Argentina \\ ${ }^{c}$ Parasitology Unit, Mycology Section, Ramos Mejía Hospital, Buenos Aires, Argentina, General Urquiza 694, CABA, Argentina \\ d Department of Microbiology, Facultad de Medicina, Universidad de Buenos Aires, Paraguay 2155, CABA, Argentina \\ e Department of Organic Chemistry, Facultad de Farmacia y Bioquímica Universidad de Buenos Aires, Junín 956, CABA, Argentina
}

\section{A R T I C L E I N F O}

\section{Article history:}

Received 16 June 2010

Received in revised form 13 October 2010

Accepted 20 October 2010

Available online 27 October 2010

\section{Keywords:}

Phenothiazines

Synthesis

Antifungal activity

$\mathrm{N}$-acyl derivatives

Pipothiazine

Promethazine

\begin{abstract}
A B S T R A C T
Several phenothiazines and related compounds were synthesized and their antifungal activity was evaluated in vitro. The results observed for $\alpha$-chloro- $N$-acetyl phenothiazine led us to choose this compound as a lead in the search of antifungal agents.
\end{abstract}

(C) 2010 Elsevier Masson SAS. All rights reserved.

\section{Introduction}

In recent years, the incidence and severity of fungal diseases has increased, particularly in patients with impaired immunity [1]. The growing number of cases of fungi involved in sepsis is a consistent trend [2], being Candida the fourth most common isolate in nosocomial bloodstream infections in some developed countries [3]. Furthermore, invasive candidiasis is a problem of growing importance in critically ill patients, such those in intensive care [4]. Besides, the mortality rate due to invasive aspergillosis in neutropenic patients has increased [5]. Superficial mycoses, such dermatophytosis or either infections caused by non dermatophyte agents, are an important cause of morbidity, being more severe in immunocompromised patients. Due to the increase in clinically important fungal infections and the small number of available antifungal agents, as well as to the appearance of antifungal resistance, searching for new, more effective and less toxic drugs is mandatory [6].

\footnotetext{
* Corresponding authors at: Department of Pharmacology, Facultad de Farmacia y Bioquímica, Universidad de Buenos Aires, Junín 956, CABA, Argentina.

E-mail addresses: rvitale@conicet.gov.ar (R.G. Vitale), amoglio@ffyb.uba.ar (A.G. Moglioni).
}

Phenothiazines and related compounds, including tranquilizers [7] and drugs with anti-inflammatory [8], antimalarial [9], antipsychotic [10], antimicrobial [11], antitubercular [12,13], antitumor [14-16], antihistaminic [17] and analgesic [18] properties, have found widespread use in medicinal chemistry. Among these, those that act as antihistaminic and antipsychotic agents are the ones most exploited therapeutically. In these compounds, the amino alkyl side chain connected to the nitrogen atom of the heterocyclic unit plays a crucial role in their properties $[19,20]$. In the last decade, the antifungal properties of some antipsychotic phenothiazine derivatives, such as trifluoroperazine, chlorpromazine and fluphenazine, have been described (Chart 1) [21].

In the course of a research program in medicinal chemistry with the aim to discover phenothiazines with antifungal action alone, we evaluated pipothiazine (PIP), a neuroleptic phenothiazine, promethazine (PMZ), an antihistaminic phenothiazine, and a series of $\mathrm{N}$-acyl and $\mathrm{N}$-alkyl phenothiazine derivatives. Based on the results observed when evaluating their antifungal activity, some $\mathrm{N}$ acyl compounds resulting from isosteric replacements and opening or ring contraction in the phenothiazine core were prepared. Then, with the battery of compounds available, we attempted to establish some structure activity relationships. 


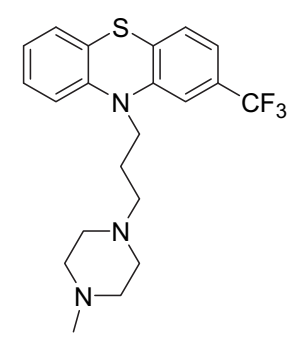

TRIFLUOROPERAZINE<smiles>CN(C)CCCN1c2ccccc2Sc2ccc(Cl)cc21</smiles>

CHLORPROMAZINE

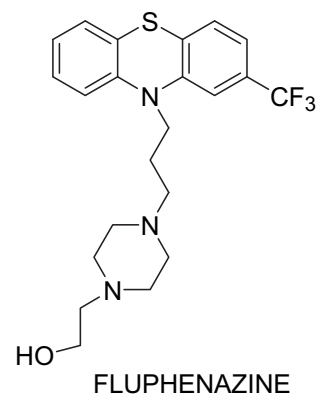

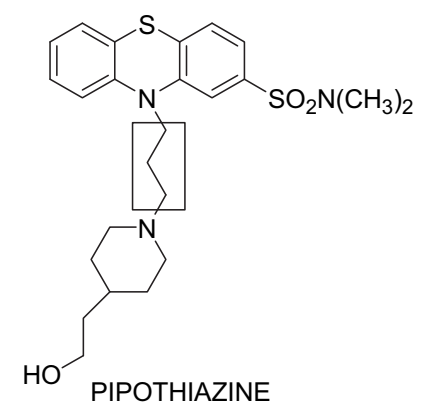

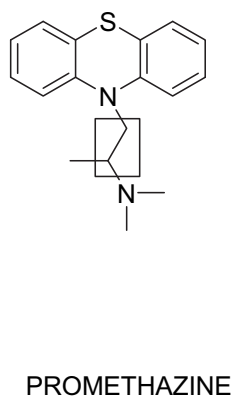

Chart 1. Structures of some antihistaminic and neuroleptic phenothiazines.

\section{Chemistry}

We have previously described the synthesis of compound $\mathbf{1}$, as starting material in the procedure to prepare the neuroleptic compound PIP [22].

Compound 1, treated with $\beta$-Cl-propanoyl chloride, afforded compound $\mathbf{2}$, which was reacted with the commercially available compound 3, to give PIP (Scheme 1).

The $N$-acyl derivatives $\mathbf{2}$ [22], $\mathbf{4}$ [22], 6 [23], 7 [24], and $\mathbf{8}$ (Chart 2) were synthesized using microwave irradiation (MW), with excellent yield and very short times of reaction, starting from the corresponding amines and using $\beta$-chloro propanoyl chloride $(\mathbf{2}, \mathbf{4})$, $\alpha$-chloro acetyl chloride $(\mathbf{6}, \mathbf{8})$ and acetyl chloride (7).

$\mathrm{N}$-acyl derivatives $\mathbf{4}$ and $\mathbf{6}$ were transformed into the $\mathrm{N}$-alkyl compounds 5 and $\mathbf{9}$ [25] by reduction with borane generated in situ (Chart 3).

The $N$-acyl derivatives $\mathbf{1 0}$ and $\mathbf{1 1}$ [26] were also prepared using MW starting from the corresponding amine and $\alpha$-chloro acetyl chloride. Compound 12 [27] was synthesized by a conventional procedure using acetyl chloride and carbazole (commercial) (Chart 4).

The nitro compound $\mathbf{1 3}$, previously prepared by us [22], was reduced using $\mathrm{Zn} / \mathrm{CaCl}_{2}$, affording compound 14. Treatment of this amine with $\alpha$-chloro-acetyl chloride and MW, gave the $N$-acyl derivative 15, with good yield and very short time of reaction (Scheme 2).

The spectroscopic behavior observed in the ${ }^{1} \mathrm{H}-\mathrm{NMR}$ spectra of compounds $\mathbf{2}$ and $\mathbf{8}$ showed the diastereotopicity of the hydrogen atoms attached to the methylene carbon in alpha position to the carbonyl group [23], which would indicate the presence of chirality in the phenothiazine system.

\section{Results and discussion}

Since the antifungal activity of PIP and PMZ commercially available were evaluated, showed good agreement with that previously described for trifluoperazine, chlorpromazine, and fluphenazine, we decided to evaluate the synthetic precursors of PIP (Scheme 1). Compound 1 showed slight antifungal activity and the synthetic precursors $\mathbf{2}$ and $\mathbf{3}$ showed no antifungal properties.

It was observed that the presence of an electron withdrawing group in the 2-position of the tricycle system is essential for neuroleptic activity, so compound $\mathbf{4}$ was prepared and evaluated as antifungal agent. Neither compound $\mathbf{4}$ nor its reduced derivative $\mathbf{5}$ showed antifungal activity.

Given the fact that the length of the carbon chain joined to the $\mathrm{N}-10$ atom is very important in the physiological activity (antihistaminic $v s$ antipsychotic) and due to the antifungal activity of PMZ

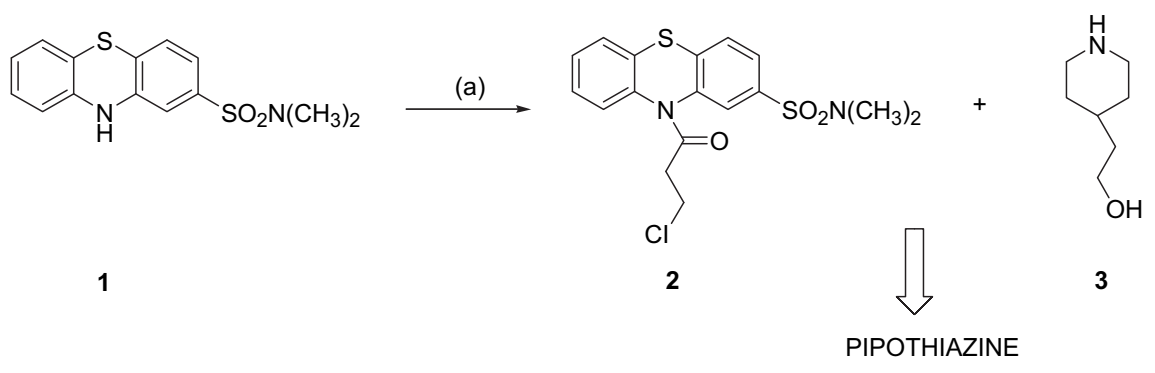

Scheme 1. Reagents: (a) $\beta$-Cl-propanoyl chloride. 
<smiles>O=C(CCCl)N1c2ccccc2Sc2ccccc21</smiles>

4<smiles>O=C(CCl)N1c2ccccc2Sc2ccccc21</smiles>

6<smiles>CC(=O)N1c2ccccc2Sc2ccccc21</smiles>

7<smiles>CN(C)OS(=O)(=O)c1ccc2c(c1)N(C(=O)CCl)c1ccccc1S2</smiles>

8

Chart 2. $\mathrm{N}$-acyl phenothiazines prepared.

observed, compound $\mathbf{6}$ was synthesized and evaluated. Surprisingly, compound $\mathbf{6}$ was found to be active against different strains of yeasts and molds (Table 1 ).

Due to the activity observed in compound $\mathbf{6}$, other $N$-acyl ( 7 and 8) and $N$-alkyl (9) derivatives were prepared and evaluated. None of these three compounds were active against the strains tested. Finally, with the aim to achieve a better approximation to the structure-activity relationship, some molecules with modifications at different levels of compound $\mathbf{6}$ were synthesized:

a. Isosteric replacement of sulfur by oxygen atom (10).

b. Opening of the phenothiazine system to obtain the corresponding dianiline (11) or diphenylthioether (15). This compound was obtained from acylation of $\mathbf{1 4}$ with $\alpha$-chloro acetyl chloride.

c. Contraction of the heterocyclic ring (12).

The results obtained showed that none of these compounds ( $\mathbf{1 0}$, 11, 12 and 15) inhibited the growth of the fungi tested.

\section{Conclusion}

We prepared thirteen phenothiazine derivatives and related compounds and tested the antifungal activity of all the compounds synthesized as well as of commercially available ones, such as PMZ and compound 3. We found that only PMZ, PIP, and compound 6 showed interesting activity. Compound $\mathbf{6}$, the simplest of the compounds tested, showed to be as active as antifungal agents currently used in clinical practice. The open analogs (11 and 15) of compound $\mathbf{6}$ were inactive. Replacement of the sulfur atom by oxygen (10) or the elimination of the sulfur atom (12) led to loss of activity. We can thus conclude that the phenothiazine ring is necessary for antifungal activity, but only some pattern of substitution in it led to the observed activity. Thus, despite there are not breakpoints for the antifungal drugs, 6 could be a promising drug since the MIC values are some comparable with those observed for the conventional antifungal agents. The most striking finding of this study was the separation of the antifungal effect in compound $\mathbf{6}$ from the antihistaminic activity of PMZ and from the antipsychotic activity of the PIP, both of which also had antifungal activities.<smiles>ClCCCN1c2ccccc2Sc2ccccc21</smiles>

5<smiles>ClCCN1c2ccccc2Sc2ccccc21</smiles>

9

\section{Experimental section}

\subsection{Chemistry}

NMR spectra were recorded $\left(\mathrm{CDCl}_{3}\right)$ on a Bruker $\mathrm{AC} 300$ or on an Avance 500 spectrometers. Shifts reported are relative to the signal of the solvent used in each case and coupling constants are reported in $\mathrm{Hz}$ (s: singlet, bs: broad singlet, d: doublet, t: triplet, dd: double doublet, dt: double triplet, m: multiplet). IR spectra were recorded using a Perkin Elmer Spectrum One FT-IR spectrophotometer. High resolution mass spectra were obtained on Bruker carried out in a household MW oven Electrolux EH-20D. Preparative thin layer chromatography (p-TLC) was done on Merck Silica Gel $60 \mathrm{GF}_{254}$; and analytical TLC was performed on Merck aluminum sheets Silica Gel 60 GF $_{254}$. Commercial compounds were purchased Aldrich Chemical Co. THF was distilled from sodium/ benzophenone. Melting points are uncorrected and were determined in a Thomas Hoover apparatus. Compound 12, whose data do not match with those in the literature was described as new compound.

\subsubsection{General procedure for obtaining the $N$-acyl-derivatives}

\section{$(2,4,6,7,8,10,11,15)$}

To a solution of $10 \mathrm{H}$-phenothiazine $(2.62 \mathrm{mmol})$ in dry toluene $(5 \mathrm{~mL})$ was added drop by drop the corresponding acyl chloride $(0.5 \mathrm{~mL} ; 6.2 \mathrm{mmol})$. The reaction was irradiate with MW (500 Watts) during $10 \mathrm{~min}$, then was washed with $\mathrm{NaOH} 5 \%$ $(2 \times 5 \mathrm{~mL})$ and the organic phase was dry with anhydrous $\mathrm{Na}_{2} \mathrm{SO}_{4}$. Finally the solvent was remove in vacuo.

5.1.1.1. 10-(3-Chloropropionyl)-N,N-dimethyl-10H-phenothiazine2 -sulfonamide 2 . This compound was obtained as a white solid. It was purified by p-TLC using as eluent hexane:dichloromethane (1:4 v/v). MP: $195-198{ }^{\circ} \mathrm{C}$, yield $62 \%$. The physical and spectroscopic data were consistent with those previously reported in the literature [22].

5.1.1.2. 10-(3-Chloropropionyl)-10H-phenothiazine 4. This compound was obtained as a white solid. It was purified by p-TLC using as eluent hexane:dichloromethane (1:3 v/v). MP: $127-130^{\circ} \mathrm{C}$, yield 91\%. The physical and spectroscopic data were consistent with those previously reported in the literature [22].
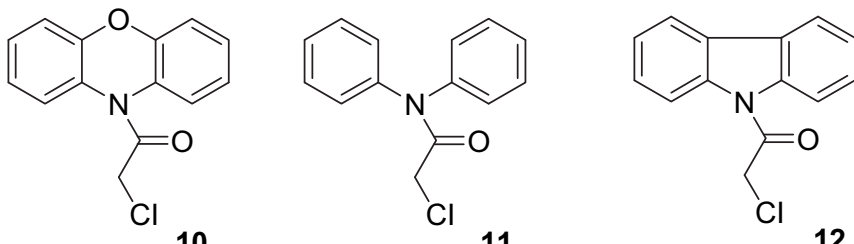
micrOTOF-Q II spectrometer. Microwave-assisted reactions were 
<smiles>O=[N+]([O-])c1ccccc1Sc1ccccc1</smiles>

13 (a)<smiles>Nc1ccccc1Sc1ccccc1</smiles>

14<smiles>Cc1ccccc1Sc1ccccc1NC(=O)CCl</smiles>

15

Scheme 2. Reagents: (a) $\mathrm{Zn} / \mathrm{CaCl}_{2}$; (b) $\alpha$-chloro-acetyl chloride, MW.

5.1.1.3. 10-(Chloroacetyl)-10H-phenothiazine 6. This compound was obtained as a white solid. It was purified by p-TLC using as eluent hexane:dichloromethane (1:3 v/v). Mp: $112-114 \mathrm{C}^{\circ}$, yield $92 \%$. The physical and spectroscopic data were consistent with those previously reported in the literature [23].

5.1.1.4. 10-(Acetyl)-10H-phenothiazine 7. It was obtained as a white solid from phenothiazine. It was purified by p-TLC using as eluent hexane:dichloromethane $(1: 2 \mathrm{v} / \mathrm{v})$. Mp: $196-199{ }^{\circ} \mathrm{C}$; yield $94.5 \%$. The physical and spectroscopic data were consistent with those previously reported in the literature [24].

5.1.1.5. 10-(Chloroacetyl)-N,N-dimethyl-10H-phenothiazine-2-sulfon amide $\boldsymbol{8}$. It was obtained as a yellow solid from compound $\mathbf{1}$ and was purified by p-TLC using as eluent hexane:dichloromethane (1:4 v/v). Mp: $205^{\circ} \mathrm{C}(\mathrm{d})$, yield 50\%. IR (Nujol, $\left.\mathrm{cm}^{1}\right): 1696(\mathrm{C}=\mathrm{O}), 1339$ $\left(\mathrm{SO}_{2} \mathrm{~N}\left(\mathrm{CH}_{3}\right)_{2}\right), 1154\left(\mathrm{SO}_{2} \mathrm{~N}\left(\mathrm{CH}_{3}\right)_{2}\right) .{ }^{1} \mathrm{H}-\mathrm{NMR}\left(400 \mathrm{MHz}, \mathrm{CDCl}_{3}\right): \delta 2.71$ $\left(\mathrm{s}, 6 \mathrm{H}, \mathrm{SO}_{2} \mathrm{~N}\left(\mathrm{CH}_{3}\right)_{2}\right), 4.06(\mathrm{~d}, J=13.6 \mathrm{~Hz}, 1 \mathrm{H},-\mathrm{CHHCI}), 4.24(\mathrm{~d}$, $J=12.8 \mathrm{~Hz}, 1 \mathrm{H},-\mathrm{CHHCI}), 7.27\left(\mathrm{dt}, J_{\mathrm{o}}=7.6 \mathrm{~Hz} J_{\mathrm{m}}=1.6 \mathrm{~Hz}, 1 \mathrm{H}, \mathrm{Ar}\right)$, $7.34\left(\mathrm{dt}, J_{\mathrm{o}}=7.6 \mathrm{~Hz} J_{\mathrm{m}}=1.6 \mathrm{~Hz}, 1 \mathrm{H}, \mathrm{Ar}\right), 7.44(\mathrm{~d}, J=7.6 \mathrm{~Hz}, 2 \mathrm{H}, \mathrm{Ar})$, $7.51\left(\mathrm{~d}, J_{\mathrm{o}}=8.4 \mathrm{~Hz}, 1 \mathrm{H}, \mathrm{Ar}\right), 7.58\left(\mathrm{dd}, J_{\mathrm{o}}=8.0 \mathrm{~Hz} J_{\mathrm{m}}=1.6 \mathrm{~Hz}, 1 \mathrm{H}, \mathrm{Ar}\right)$, $7.97\left(\mathrm{~d}, J_{\mathrm{m}}=1.6 \mathrm{~Hz}, 1 \mathrm{H}, \mathrm{Ar}\right) \mathrm{ppm} .{ }^{13} \mathrm{C}-\mathrm{NMR}\left(75 \mathrm{MHz}, \mathrm{CDCl}_{3}\right): \delta 165.6$, 138.0, 136.9, 134.2, 129.8, 128.6, 128.2, 128.0, 126.6, 126.2, 41.7, $38.1 \mathrm{ppm}$. HRMS (ESI): calcd for $\mathrm{C}_{16} \mathrm{H}_{15} \mathrm{O}_{3} \mathrm{~S}_{2} \mathrm{~N}_{2} \mathrm{ClNa}$, 405.0105, found 405.0108 .

5.1.1.6. 10-(Chloroacetyl)-10H-phenoxazine 10. It was obtained as a white solid from phenoxazine. It was purified by p-TLC using as eluent hexane:dichloromethane $(1: 2 \mathrm{v} / \mathrm{v})$. Mp: $140-142{ }^{\circ} \mathrm{C}$, yield 91\%. IR ( $\left.\mathrm{KBr}, \mathrm{cm}^{-1}\right): 1675(\mathrm{C}=\mathrm{O}) .{ }^{1} \mathrm{H}-\mathrm{NMR}\left(300 \mathrm{MHz}, \mathrm{CDCl}_{3}\right): \delta 4.35$ (s, 2H, CH $\mathrm{Cl}_{2} \mathrm{Cl}$ ), 7.14-7.28 (m, 6H, Ar), 7.58 (d, J=7.7 Hz, 2H, Ar) ppm. ${ }^{13} \mathrm{C}$-NMR (75 MHz, $\mathrm{CDCl}_{3}$ ): $\delta$ 41.5, 117.1, 123.7, 124.3, 127.6, 128.5, 150.9, $165.3 \mathrm{ppm}$. HRMS (ESI): calcd for $\mathrm{C}_{14} \mathrm{H}_{11} \mathrm{O}_{2} \mathrm{NCl}, 260.0473$, found, 260.0482 .

Table 1

MICs $(\mu \mathrm{g} / \mathrm{mL})$ values of compounds PIP, PMZ, 6 and those used as reference drugs.

\begin{tabular}{|c|c|c|c|c|c|c|c|c|}
\hline \multirow[t]{2}{*}{ Assayed fungi } & \multicolumn{8}{|c|}{ Evaluated drugs and calculated MICs $(\mu \mathrm{g} / \mathrm{mL})$} \\
\hline & PIP & PMZ & 6 & AMB & $\mathrm{FCZ}$ & ITZ & $\mathrm{TBF}$ & $5 \mathrm{FC}$ \\
\hline C. albicans & 256 & $>512$ & 32 & 0.5 & 2 & 0.125 & 0.5 & 2 \\
\hline C. parapsilosis & 256 & 512 & 32 & 0.5 & 1 & 0.125 & 0.06 & 0.5 \\
\hline C. glabrata & 256 & $>512$ & $>512$ & 0.25 & 1 & 0.25 & 0.06 & 1 \\
\hline C. krusei & 512 & 256 & 32 & 0.25 & 64 & 0.06 & 0.06 & 0.5 \\
\hline C. guillermondii & 256 & 512 & 32 & 1 & 4 & 0.5 & 0.5 & 1 \\
\hline C. neoformans & 256 & 256 & 8 & 0.5 & 8 & 0.25 & 0.25 & 0.5 \\
\hline A. fumigatus & $>512$ & 256 & 16 & 0.5 & 16 & 0.25 & 0.25 & 0.5 \\
\hline A. flavus & $>512$ & 256 & 32 & 0.25 & 16 & 0.125 & 0.25 & 1 \\
\hline A. niger & $>512$ & 256 & 2 & 0.5 & 16 & 0.125 & 0.125 & 0.5 \\
\hline A. terreus & $>512$ & 256 & 16 & 2 & 16 & 0.125 & 0.06 & 1 \\
\hline C. carrionii & 256 & 512 & 4 & 1 & 8 & 0.06 & 0.25 & 1 \\
\hline E. spinifera & 256 & 256 & 16 & 1 & 16 & 0.06 & 0.06 & 2 \\
\hline E. oligosperma & 512 & 256 & 16 & 1 & 8 & 0.125 & 0.06 & 4 \\
\hline E. xenobiotica & 512 & 256 & 16 & 1 & 16 & 0.06 & 0.06 & 8 \\
\hline
\end{tabular}

5.1.1.7. 2-Chloro-N,N-diphenylacetamide 11. This compound was obtained as a white solid and purified by p-TLC using hexane:dichlorometane $(1: 3 \mathrm{v} / \mathrm{v})$. Mp: $116-118{ }^{\circ} \mathrm{C}$, yield $90 \%$. The physical and spectroscopic data were consistent with those previously reported in the literature [26].

5.1.1.8. 2-(N-Chloroacetylamine)-1-phenylthiobenzene 15. Compound 2-nitro-diphenylthiobenzene (13) [22] (500 mg, $2.16 \mathrm{mmol}$ ) was reduced with $\mathrm{Zn}^{\circ}(4.6 \mathrm{~g})$ and $\mathrm{CaCl}_{2}(155 \mathrm{mg})$ in ethanol $78 \%$ $(15.5 \mathrm{~mL})$. The mixture was refluxed during $2 \mathrm{~h}$. Then was filtered and the solvent was removed in vacuo. The amine $\mathbf{1 4}$, obtained as a yellow oil, was purified by p-TLC using as eluent hexane:dichloromethane 1:1, yield 94\%. IR (film): $3468(\mathrm{NH}), 3371(\mathrm{NH}) .{ }^{1} \mathrm{H}-$ NMR (300 MHz), $\left.\mathrm{CDCl}_{3}\right): \delta 4.47\left(\mathrm{~s}, 2 \mathrm{H}, \mathrm{NH}_{2}\right), 6.95$ (m, 2H, Ar), 7.29 $(\mathrm{m}, 3 \mathrm{H}, \mathrm{Ar}), 7.41(\mathrm{~m}, 3 \mathrm{H}, \mathrm{Ar}), 7.65(\mathrm{dd}, 1 \mathrm{H}, \mathrm{Ar}) \mathrm{ppm} .{ }^{13} \mathrm{C}-\mathrm{NMR}$ (75 MHz), $\mathrm{CDCl}_{3}: \delta 114.2,115.3,118.7,125.4,126.4,128.9,131.1,136.7$, $137.4,148.8 \mathrm{ppm}$.

The amine 14 was used to prepare compound 15 by the general procedure. Compound 15 was obtained as a white solid and purified by p-TLC using hexane:dichlorometane $(1: 2 \mathrm{v} / \mathrm{v}) . \mathrm{Mp}$ : 65-66 ${ }^{\circ} \mathrm{C}$, yield 91\%. IR (Nujol, $\mathrm{cm}^{-1}$ ): $3315(\mathrm{NH}), 1700(\mathrm{C}=0), 1685$ $(\mathrm{C}=\mathrm{N}) .{ }^{1} \mathrm{H}-\mathrm{NMR}\left(300 \mathrm{MHz}, \mathrm{CDCl}_{3}\right): \delta 4.08\left(\mathrm{~s}, 2 \mathrm{H},-\mathrm{CH}_{2} \mathrm{CI}\right), 7.09-7.27$ (m, 6H, Ar), 7.47 (t, $J=8.2 \mathrm{~Hz}, 1 \mathrm{H}, \mathrm{Ar}), 7.63(\mathrm{~d}, J=7.7 \mathrm{~Hz}, 1 \mathrm{H}, \mathrm{Ar}), 8.4$ (d, $J=8.2 \mathrm{~Hz}, 1 \mathrm{H}, \mathrm{Ar}), 9.5(\mathrm{~s}, 1 \mathrm{H}, \mathrm{NH}) \mathrm{ppm} .{ }^{13} \mathrm{C}-\mathrm{NMR}(75 \mathrm{MHz}$, $\left.\mathrm{CDCl}_{3}\right): \delta 43.0,120.7,121.5,125.2,126.4,127.6,129.2,130.8,135.2$, 136.6, 138.7, $163.9 \mathrm{ppm}$. HRMS (ESI): calcd for $\mathrm{C}_{14} \mathrm{H}_{12} \mathrm{ONSClNa}$, 300.0220, found, 300.0231 .

\subsubsection{0-(Chloroacetyl)-10H-carbazole 12}

To a solution of carbazole $(400 \mathrm{mg}, 2.39 \mathrm{mmol})$ in dry DMF ( $4 \mathrm{~mL}$ ) was added drop by drop $\alpha$-chloro acetyl chloride $(0.95 \mathrm{ml})$. The reaction was maintaining to $80^{\circ} \mathrm{C}$ for $2 \mathrm{~d}$. The solvent was remove in vacuo and the reaction mixture was treated with a solution of $\mathrm{NaOH} 5 \%$ and extracted with dichloromethane $(3 \times 10 \mathrm{~mL})$. Then the organic layer was dried over anhydrous $\mathrm{Na}_{2} \mathrm{SO}_{4}$. The solvent was removed in vacuo and the crude product was purified by p-TLC using as eluent hexane:dichloromethane (1:1 $\mathrm{v} / \mathrm{v})$. Compound 12 was obtained as a white solid. Mp: $88-92{ }^{\circ} \mathrm{C}$, yield $90 \%$. IR $\left(\mathrm{KBr}, \mathrm{cm}^{-1}\right)$ : $1699(\mathrm{C}=\mathrm{O}) .{ }^{1} \mathrm{H}-\mathrm{NMR}\left(500 \mathrm{MHz}, \mathrm{CDCl}_{3}\right)$ : $\delta 4.72\left(\mathrm{~s}, 2 \mathrm{H}, \mathrm{CH}_{2} \mathrm{CI}\right), 7.45(\mathrm{t}, J=10 \mathrm{~Hz}, 2 \mathrm{H}, \mathrm{Ar}), 7.55(\mathrm{t}, J=10 \mathrm{~Hz}, 2 \mathrm{H}$, $\mathrm{Ar}), 8.03$ (d, $J=10 \mathrm{~Hz}, 2 \mathrm{H}, \mathrm{Ar}), 8.2(\mathrm{~d}, J=10 \mathrm{~Hz}, 2 \mathrm{H}, \mathrm{Ar}) \mathrm{ppm} .{ }^{13} \mathrm{C}-$ $\operatorname{NMR}\left(75 \mathrm{MHz} \mathrm{CDCl}_{3}\right): \delta 44.9,116.2,120.0,124.4,126.7,127.6,137.9$, $165.6 \mathrm{ppm}$. HRMS (ESI): calcd for $\mathrm{C}_{14} \mathrm{H}_{11} \mathrm{ONCl}, 244.0524$, found, 244.0530 .

\subsubsection{General procedure for obtaining the $N$-alkyl-derivatives $(\mathbf{5}, \mathbf{9})$}

Borane gas was generated from a mixture of $\mathrm{NaBH}_{4}(1.6 \mathrm{~g})$ in diethylene glycol dimethyl ether $(6 \mathrm{~mL})$ and trifluoroboroetherate $(5.4 \mathrm{~mL})$ was bubbled on the corresponding $N$-acyl-derivative $(0.91 \mathrm{mmol})$ in dry THF $(10 \mathrm{~mL})$. Then the solution was stirred during $72 \mathrm{~h}$ at room temperature. After that, the solution was adjusted to $\mathrm{pH}=8$ by slowly adding of $1 \mathrm{~N} \mathrm{HCl}$ and the product was 
extracted with several portions of dichloromethane. The organic extract was dried with anhydrous $\mathrm{Na}_{2} \mathrm{SO}_{4}$ and the solvent was removed in vacuo and was purified by p-TLC.

5.1.3.1. 10-(3-Chloropropyl-)-10H-phenothiazine 5. It was obtained as a green solid and purified by p-TLC using hexane:dichlorometane $(1: 1 \mathrm{v} / \mathrm{v})$. Mp: $60-61^{\circ} \mathrm{C}$, yield $88 \%$. IR $\left(\mathrm{KBr}, \mathrm{cm}^{-1}\right)$ : $1284(\mathrm{C}-\mathrm{N}), 1252(\mathrm{C}-\mathrm{N}) .{ }^{1} \mathrm{H}-\mathrm{NMR}\left(300 \mathrm{MHz}, \mathrm{CDCl}_{3}\right): \delta 2.24(\mathrm{~m}, 2 \mathrm{H}$, $\left.\mathrm{C}-\mathrm{CH}_{2}-\mathrm{C}\right), 3.68\left(\mathrm{t}, J=6.2 \mathrm{~Hz}, 2 \mathrm{H},-\mathrm{N}-\mathrm{CH}_{2}-\mathrm{C}\right), 4.11(\mathrm{t}, J=6.6 \mathrm{~Hz}$, $\left.2 \mathrm{H},-\mathrm{CH}_{2}-\mathrm{CI}\right), 6.93(\mathrm{~m}, 4 \mathrm{H}, \mathrm{Ar}), 7.19(\mathrm{~m}, 4 \mathrm{H}, \mathrm{Ar}) \mathrm{ppm} .{ }^{13} \mathrm{C}-\mathrm{NMR}$ $\left(125 \mathrm{MHz}, \mathrm{CDCl}_{3}\right): \delta 29.6,42.4,44.0,115.6,122.8,125.7,127.3,127.6$, 145.0 ppm. HRMS (ESI): calcd for $\mathrm{C}_{15} \mathrm{H}_{14} \mathrm{NSClNa}$, 298.0427, found, 298.0428

5.1.3.2. 10-(2-Chloroetyl)-10H-phenothiazine 9. This compound was obtained as a green solid and was purified by p-TLC using as eluent hexane:dichloromethane ( $1: 1 \mathrm{v} / \mathrm{v})$. Mp: $94-95^{\circ} \mathrm{C}$, yield $85 \%$. The physical and spectroscopic data were consistent with those previously reported in the literature [25].

\subsection{Antifungal activity}

Compounds described above (1-12 and 15) were evaluated by diffusion methodology as screening. From all, halo of inhibition was observed only for PIP, PMZ, compound $\mathbf{1}$ and $\mathbf{6}$. Then, the antifungal activity of these four compounds and several antifungal agents in clinical use against yeasts and molds were evaluated following the CLSI (Clinical and Laboratory Standards Institute) guidelines (formerly NCCLS), document M27A2 and M38A2 [28,29]. The drugs evaluated were: amphotericin B (AMB), itraconazole (ITZ), fluconazole (FCZ), terbinafine (TBF), flucytosin (5FC), PIP, PMZ, compound $\mathbf{1}$ and compound $\mathbf{6}$. The assayed yeasts were: Candida albicans, Candida parapsilosis, Candida glabrata, Candida krusei, Candida guillermondii, Cryptococcus neoformans. The filamentous fungi included: Aspergillus fumigates, Aspergillus flavus, Aspergillus niger, Aspergillus nidulans, Aspergillus terreus, Cladophialophora carrionii and black yeasts: Exophiala spinifera, Exophiala oligosperma, Exophiala xenobiotica. Briefly fungi were growth onto Saboureaud glucose agar, during 2 days for yeasts and up to 7 days for the molds. For each drug, stock solutions were prepared and diluted in the appropriate solvent to be inoculated into 96-wellflat-bottom micro titer plates. Fungi inoculum was prepared according with the CLSI and inoculated into the plates. Final inoculums for yeasts was $0.5-5 \times 10^{3} \mathrm{CFU} / \mathrm{ml}$, and for filamentous fungi $0.5-5 \times 10^{4} \mathrm{CFU} / \mathrm{ml}$. After incubation at $30^{\circ} \mathrm{C}$, spectrophotometer and visual reading were determined in order to obtain the minimal inhibitory concentration (MIC) for each strain and each drug.

Compound 1 was tested against all strains. Halo of inhibition was observed by diffusion test, but, when microdilution was performed, all strains showed MICs $>512 \mathrm{ug} / \mathrm{ml}$, indicating lacking of activity. Activity was observed for PIP and PMZ at concentrations ranged from 128 to $512 \mathrm{ug} / \mathrm{ml}$, with the exception of Aspergillus species for PIP showed MIC > $512 \mathrm{ug} / \mathrm{ml}$. Interesting was to observe the higher activity of compound $\mathbf{6}$ compared with those described above. For this drug the range was from 2 to $32 \mathrm{ug} / \mathrm{ml}$, except for $C$. glabrata, for which MIC of $>512 \mathrm{ug} / \mathrm{ml}$ was detected. All data is summarized in Table 1.

\section{Acknowledgement}

Walter Vivot and Luciana Karayan are acknowledged for their assistance. This research was supported in part by the CONICET and SECYT/UBA (Argentina).

\section{References}

[1] F.C. Odds, Trends Microbiol. 8 (2000) 200-201.

[2] G.S. Martin, D.M. Mannino, S. Eaton, M. Moss, N. Engl. J. Med. 348 (2003) 1546-1554.

[3] M.B. Edmond, S.E. Wallace, D.K. McClish, M.A. Pfaller, R.N. Jones, R.P. Wenzel, Clin. Infect. Dis. 29 (1999) 239-244.

[4] M. Morrell, V.J. Fraser, M.H. Kollef, Antimicrob. Agents Chemother. 49 (2005) 3640-3645.

[5] K. Mühlemann, C. Wenger, R. Zenhaüsem, M.G. Täuber, Leukemia 19 (2005) 545-550.

[6] R.P. Rapp, Pharmacotherapy 24 (2004) 4S-28S.

[7] M.K. El-Said, Pharmazie 36 (1981) 678-679.

[8] R. Tilak, R. Tyagi, B. Goel, K.K. Saxena, V.K. Srivastava, A. Kumar, Indian Drugs 35 (1998) 216-221 Chem. Abstr. 129 (1998) 109052

[9] J.N. Dominguez, S. Lopez, J. Charris, L. Iarruso, G. Lobo, A. Semenow, J.E. Olson, P.J. Rosenthal, J. Med. Chem. 40 (1997) 2726-2733.

[10] G. Lin, K.K. Midha, E.M. Hawes, J. Heterocycl. Chem. 28 (1991) 215-219.

[11] J. Raval, K.K. Desai, ARKIVOC xiii (2005) 21-28.

[12] M. Viveros, L. Amaral, Int. J. Antimicrob. Agents 17 (2001) 225-228 Chem. Abstr. 134 (2001) 350521.

[13] A. Trivedi, A. Siddiqui, V. Shah, ARKIVOC ii (2008) 210-217.

[14] N. Motohashi, M. Kawase, S. Saito, H. Sakagami, Curr. Drug Targets 1 (2000) 237-245 (Pub Med ID 11465073).

[15] N. Motohashi, T. Kurihara, K. Satoh, H. Sakagami, I. Mucsi, R. Pusztai, Molnar, Anticancer Res. 19 (1999) 1837-1842.

[16] T. Kurihara, N. Motohashi, G.L. Pang, M. Higno, K. Kiguchi, Molnar, Anticancer Res. 16 (1996) 2757-2765.

[17] D. Ledincer, L.A. Mitscher, Organic Chemistry of Drug Synthesis, vol. 1 (1976) $372-392$.

[18] A.A. Borbely, M. Loepfe-Hinkkanen, Mod. Pharmacol. Toxicol. 16 (1979) 403-426.

[19] W.R. Reid, J.R. Wright, H.G. Kollofe, J.H. Hunter, J. Am. Chem. Soc. 70 (1948) 3100-3102.

[20] I. Meier, Med. Monatsschr. 8 (1954) 397-399 Chem. Abstr. 48 (1954) 10225.

[21] R.G. Vitale, J. Afeltra, J.F.G.M. Meis, P.E. Verweij, Mycoses 50 (2007) 270-276.

[22] G.P. Sarmiento, G.Y. Moltrasio, A.G. Moglioni, ARKIVOC vii (2009) 33-41.

[23] S. Darvesh, R.S. McDonald, A. Penwell, S. Conrad, K.V. Darvesh, D. Mataija, G. Gomez, A. Caines, R. Walsh, E. Martin, Bioorg. Med. Chem. 13 (2005) $211-213$.

[24] J.P. Raval, K.R. Desai, ARKIVOC xiii (2005) 21-28.

[25] L. Della Ciana, I. Hamachi, T. Meyer, J. Org. Chem. 54 (1989) 1731-1735.

[26] H.R. Howard, B.K. Koe, A. Weissman, J. Med. Chem. 32 (1989) 437-444.

[27] S.K. Srivastava, S.K. Nema, A. Srivastava, Ind. J. Chem. 47B (2008) 606-612.

[28] National Committee for Clinical Laboratory Standards (2003). Reference method for broth dilution susceptibility testing of yeasts: approved standard. M27A2.

[29] National Committee for Clinical Laboratory Standards (2008). Reference method for broth dilution susceptibility testing of filamentous fungi: approved standard. M38A2. 